\title{
Experimental Evaluation of Pyroclastic Deformation on Mechanical Properties of Grès Porcelain Stoneware
}

\author{
Cristiano Fragassa ${ }^{1,}$, Ana Pavlovic ${ }^{1}$, Francesco Ubertini ${ }^{2}$ \\ ${ }^{1}$ Department of Industrial Engineering, University of Bologna, Bologna (Italy) \\ ${ }^{2}$ Department of Civil, Chemical, Environmental and Materials Engineering, University of Bologna, Bologna (Italy)
}

Grès Porcelain stoneware is a ceramic with a compact, hard, coloured and non-porous body. A very prominent patented technology permits to obtained bent porcelain tiles as innovative solutions for a modern architecture. This technology is grounded on a proper combination of heavy machining by cutting tools and secondary firing in a kiln. This paper investigates the alteration in behaviour of porcelain passing by the bending process comparing the mechanical proprieties by flexural, compression and impact tests.

Keywords: Ceramic Industry, Grès Porcelain, Secondary Firing, Experimental Tests,

\section{INTRODUCTION}

\subsection{Grès Porcelain materials}

Grès Porcelain stoneware is a ceramic with a compact, hard, coloured and non-porous body. The word "grès" means that the ceramic body of the tile is extremely vitrified, that is to say compact, hence the exceptional great resistance. The result is a lean clay body [1], little refractory, fired in a kiln (at 1200-1400 $\mathrm{C}^{\circ}$ ) until it reaches a non-porous vitrification and a complete water-proofing.

The raw materials used for the composition of mixtures from porcelain tiles are of two types [2]: clayey raw materials, which give plasticity to the mixture, and complementary raw materials (not plastic) that include melting minerals and those used for compacting or with structural functions. Of the first group are the clay minerals, as kaolinite and montmorillonite-illitics. The melting minerals, however, are feldspathoids and feldspars, talc, eurits, pegmatite; those more refractory to structural function are quartz and quartzite in gender.

Table 1, Range of percentages for raw elements in most common mixtures of Grés Porcelain stoneware

\begin{tabular}{|l|c|}
\hline \multicolumn{1}{|c|}{ Elements } & $\begin{array}{c}\text { \% } \\
\text { (in weight) }\end{array}$ \\
\hline \hline $\mathrm{SiO}_{2}$ & $\mathbf{6 4 - \mathbf { 6 8 }}$ \\
\hline \hline $\mathrm{Al}_{2} \mathrm{O}_{3}$ & $\mathbf{2 8 - 2 1}$ \\
\hline \hline $\mathrm{Fe}_{2} \mathrm{O}_{3}+\mathrm{TiO}_{2}$ & $\mathbf{0 . 3}-\mathbf{1 . 0}$ \\
\hline $\mathrm{CaO}+\mathrm{MgO}$ & $\mathbf{0 . 1}-\mathbf{0 . 9}$ \\
\hline $\mathrm{Na}_{2} \mathrm{O}$ & $\mathbf{3 . 0}-\mathbf{4 . 5}$ \\
\hline \hline $\mathrm{K}_{2} \mathrm{O}$ & $\mathbf{1 . 4}-\mathbf{2 . 9}$ \\
\hline Lost in fire & $\mathbf{3 . 4 - 7 . 8}$ \\
\hline
\end{tabular}

ISO 13006:2012 defines terms and establishes classifications, characteristics and marking requirements for ceramic with special attention to water absorption [1].

\subsection{Production technology for Grès Porcelain}

The porcelain tiles are obtained by the process of sintering of ceramic clays, feldspar, kaolin and sand. These raw materials are first ground (processed in ceramic slips), then finely atomized until a homogeneous powder particle size suitable for the pressing.

The cooking process takes place at a temperature of about $1150-1250^{\circ} \mathrm{C}$ in long kilns, up to $140 \mathrm{~m}$, where the raw material is gradually brought to the maximum temperature, maintained there for about 25-30 minutes, and cooled gradually to room temperature. The cooking process causes the vitrification of the dough, attributing the typical mechanical and chemical characteristics. During cooking various deformations occur on the matter previously pressed [2]. The size shrinkage after firing is around a $7 \%$.

Grès Porcelain records values of water absorption (i.e. the amount of water that, in particular conditions, the slab can absorb) less than $0.5 \%$, which is among the lowest of all the products for floor and wall.

From this feature also derives the highest degree of resistance to bending [5], that represents the maximum stress that the material, which is subjected to an increasing bending action, can tolerate before breaking down.

The vitrification also leads to a very high abrasion resistance, or the resistance that the surface opposed to the measures connected with the movement of bodies, surfaces or materials in contact with it.

\subsection{Advantages in use of Grès Porcelain material}

Main advantages in use of Grès Porcelain stoneware for quality architecture and building materials can be summarized as:

- Impact strength and stress resistance

- Wear resistance

- Scratching resistance

- Resistance to frost

- Resistance to chemicals

- Stain resistance 


\section{MODELLING CERAMIC TILES}

\subsection{Bending technology for Grès Porcelain}

Approximately 750 millions square meters of grès porcelain stoneware are produced every year in the World, mainly by Italy ( $>40 \%)$, China, South Asia and Spain, to be used inside or outside buildings [6]. These elements are (almost) entirely commercialized in flat slabs.

On the contrary, a very prominent patented technology [7] permits to obtained practical solutions of bended porcelain tiles, perfect for modern architecture and design. This technology is grounded on a proper combination of machining by cutting tools and secondary firing in a kiln. The line for bending consists of a special kiln, specifically designed to bend the tiles laying down special supports (Fig. 1), and an equipment set which prepares the bend/fold and finishes the piece. This innovative system allows tiles to be bent at variable angles as desired. Prior to this, similar processes were confined to the glass industry. Yet while glass can be modelled when it is still relatively "cool", doing the same with ceramic involves considerably higher temperatures.

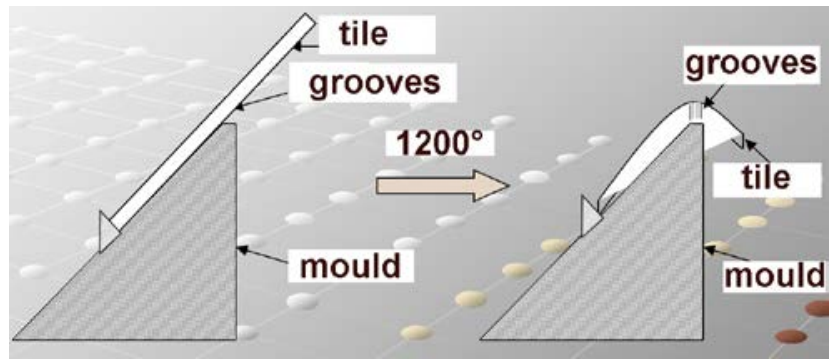

Figure 1: Bending process

Entering in details of the bending technology, the "original" material, usually in the shape of ceramic tiles, is progressively and slowly heated up. This process, known as pyroclastic deformation [8], involves subjecting the tile to an annealing at a temperature lower than that of sintering, between $1160{ }^{\circ} \mathrm{C}$ and $1210^{\circ} \mathrm{C}$, but with longer times (160-270 minutes from cold to cold) and thermal gradients smaller compared to traditional cooking. The appearance of the visco-plastic processes within the material at high temperatures allows the tile to recline to support even only due to the force of gravity, allowing to obtain the bending of the tile. This heating phase has to be thermally controlled with high accuracy (Figure 2).

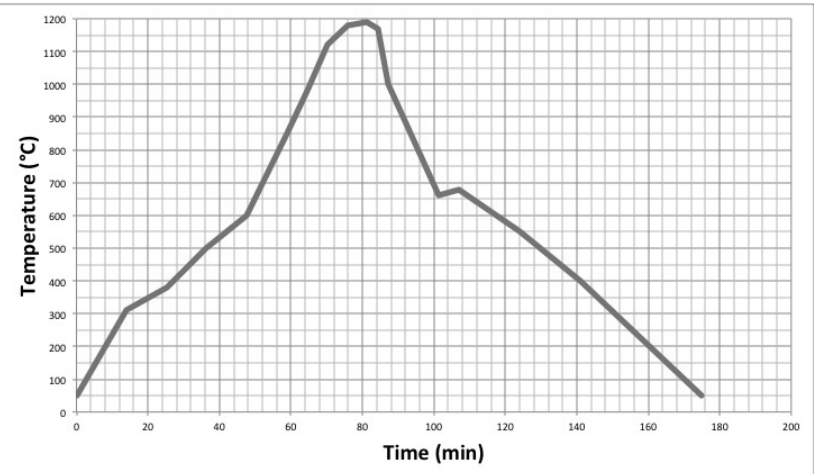

Figure 2: Temperature profile during the bending process
Each profile of temperature is developed and optimized by experience with the aim at permitting to realize each particular angle and curvature. In this way, it is possible to avoid the most relevant phenomena of modification that can occur during the phase of heating and cooling, including geometrical variations or changes in the color of ceramics.

The forming process of the tiles is controlled, in addition to the temperature, also by the application of incisions on the back of the tile [7] that act as guides for bending and the use of media of different shapes and sizes depending on the format to be obtained. The incisions are realized by the appropriate machinery and good precision; the positions and the depth of the incisions are studied by experience on the basis of the type of tile and the type of curvature requested.

As fundamental step of the production cycle, the material has to be placed on special shaped supports (Fig. 3), functionally similar to moulds, that slide inside a roller kiln able to calibrate the thermal period to which the tile must be subjected. Once the preset temperature is reached, the mass of the ceramic material, as described, deforms and adapts perfectly to the template with which it is in contact (Fig. 4). When the tile is cold, it is finished to final dimensions by grinding disc or water-jet.

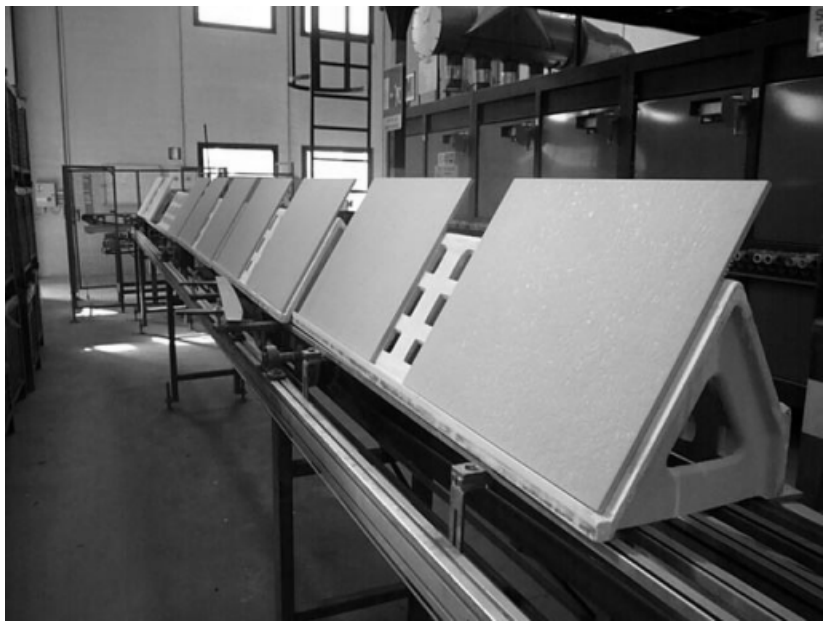

Figure 3: Tiles before bending process

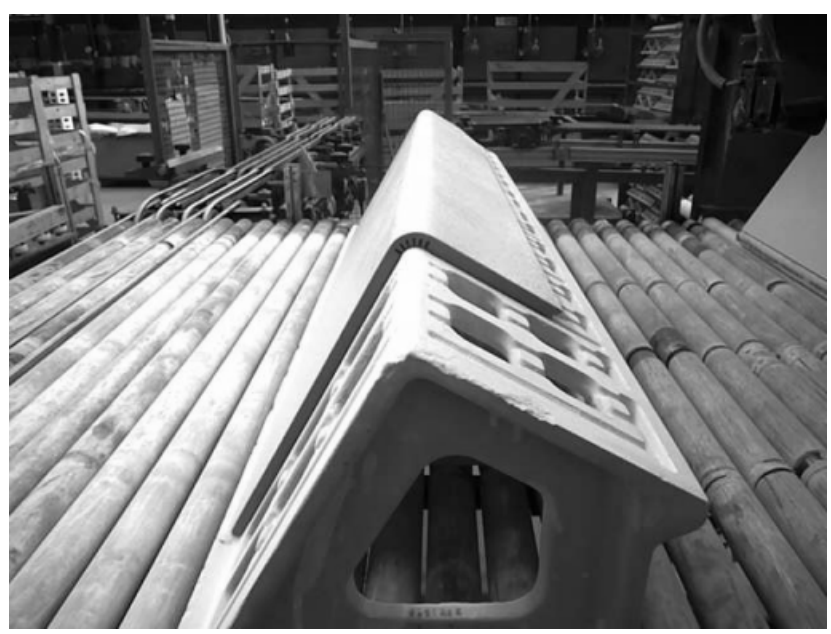

Figure 4: Tiles after bending process 


\subsection{Advantages in use of bended porcelain tiles}

The potential for the porcelain tile bending technology is enormous and cover large part of the entire world ceramic industry. Ceramic slabs can be shaped to meet specific needs. For example, architects could be able to order specially-shaped tiles to perfectly fit their projects. Main point of application is in the house and its corners. A single ceramic item that has been bent at $90^{\circ}$ can, for instance, be used to cover an entire step (Fig. 5, on the left): similarly, it can also act as a floor tile-cum-wall tile to provide an alternative to traditional skirting.
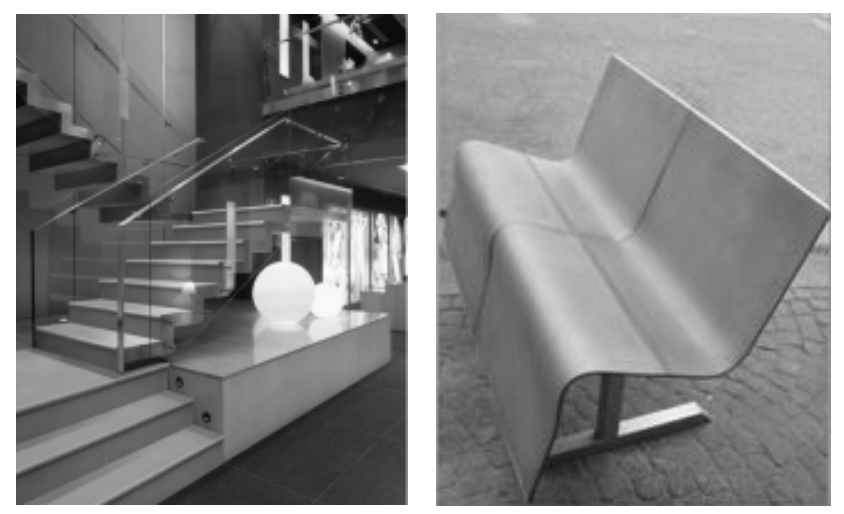

Figure 5: Advanced solutions and design permitted by bending tiles: steps and stairs (left); b) bench seats (right)

These advanced solutions for buildings offer many practical advantages as:

- less installation time and less working on site

- greater area security thanks to the no edges

- better design in products (Fig. 5b4)

- cut of stocks of special pieces

- possibility to differentiate stocks.

- more hygiene for public buildings

Referring to the last aspect, bent tiles eliminates the edges and interstices between wall and floor where dust and dirt often gather. This technical solution is ideal for hospitals and other places where cleanliness and hygiene are fundamental. And it could preserve the positioning of ceramics on the market. In fact, in all Europe, ceramic are going to be progressively banned from hospitals and other public buildings (as schools, airports, shopping centres, etc.) with the aim at eliminating interstices, as referred by UE Rule 852/2004 for hygiene into public buildings [8].

It is worth noting that ISO $13006: 2012$ [1] is not applicable to decorative accessories or trim, such as edges, corners, skirting, capping, coves, beads, steps, curved tiles. Consequently, ISO 13006:2012 is not applicable to bent ceramic tiles; then, specific rigor has to be reserved to the production and installation of these elements.

Between other features, the necessity to reinforce the bent area of the tile, weakened by grooves, is an important aspect. An efficient recently patented solution fills grooves with a filling material, compatible with the material of which the tile is made. Then it covers the grooves with a flexible strip of incombustible refractory-material, anchors the strip to the surface of the tile, heats the area to be bent up to the softening temperature of the area itself and, finally, cools the modelled tile thus obtained [1].

\section{EXPERIMENTAL ANALYSIS}

\subsection{Materials and Methods}

This paper investigates the alteration in the mechanical behaviour of a specific grès porcelain stoneware passing by the pyroclastic deformation as required inside the bending process. Results are obtained comparing mechanical proprieties and resistance by experimental tests. This mechanical characterization was realized on a commercial fine porcelain stoneware, produced by FloorGress and branded as FloorTech ${ }^{\circledR}$.

Table 2, Technical specifications for grès porcelain stoneware declared by the producer

\begin{tabular}{|c|c|c|c|c|}
\hline \multicolumn{2}{|c|}{$\begin{array}{c}\text { Specification } \\
\text { reference }\end{array}$} & \multirow{2}{*}{$\begin{array}{c}\begin{array}{c}\text { Test } \\
\text { method }\end{array} \\
\begin{array}{c}\text { ISO- } \\
10545-3\end{array}\end{array}$} & \multirow{2}{*}{\begin{tabular}{|c}
$\begin{array}{c}\text { Reference } \\
\text { value }\end{array}$ \\
$<0,5 \%$
\end{tabular}} & \multirow{2}{*}{\begin{tabular}{|c|}
$\begin{array}{c}\text { Declared } \\
\text { value }\end{array}$ \\
$<0,1 \%$
\end{tabular}} \\
\hline & $\begin{array}{c}\text { Water } \\
\text { absorbed }\end{array}$ & & & \\
\hline & $\begin{array}{l}\text { Breaking } \\
\text { strength }\end{array}$ & \multirow{2}{*}{$\begin{array}{c}\text { ISO- } \\
10545-4\end{array}$} & $\begin{array}{c}\geq 1300 \\
\mid \text { Newton }\end{array}$ & $>1700$ \\
\hline & $\begin{array}{l}\text { Bending } \\
\text { strength }\end{array}$ & & $\begin{array}{c}>35 \\
\mathrm{~N} / \mathrm{mm}^{2}\end{array}$ & $>40$ \\
\hline
\end{tabular}

Experimental tests were realized according to the ASTM standards with the aim at evaluating the mechanical properties related to the flexural, compressive and impact behaviour. For each of these 3 tests, two different testing sessions were arranged, involving samples from ceramic tiles before and after the bending process.

To minimize the variability of unexpected factors, samples were obtained by a same lot of ceramics tiles and process parameters (es. times and temperatures) were maintain as constants during the bending process. Adding, many effort at reducing uncertainty, specific attention were used to extract samples from similar zones in the tiles and also to limit the residual stress (related, e.g., to tool cutting processes).

\subsection{Experimental Equipment}

Test were realized using an INSTRON mod. 8033 servohydraulic testing frame fatigue machine, with a load capacity up to $250 \mathrm{kN}$. It was equipped with a load cell of $2 \mathrm{kN}$ or $25 \mathrm{kN}$ according to the specific test and provisional range of loads. Specimens were loaded in control of displacement. Data were acquired by MTS Test Star IIs 2s Digital Controller with an acquisition rate of $10 \mathrm{~Hz}$. Grips and fixtures were selected according to the standards.

\subsection{Measures and results}

For each specimen, tests and calculations permitted to determinate:

- the force-displacement diagram

- the breaking loads and displacements

- the breaking strength and deformation

- the stress-strain diagram and related mean values/diagrams for samples. These experimental evidences were used to verify alteration in the mechanical proprieties of samples. 


\section{FLEXURAL TESTS}

4.1. Determination of flexural breaking strength

Flexural breaking strength of all ceramic tiles were evaluated in accordance with ISO 10545 [10] by a three point flexural test. It permits the determination of the breaking load, breaking strength and modulus of rupture of a tile by applying a bending force at a specified rate to the centre of the tile, the point of application being in contact with the proper surface of the tile (Fig. 6).

Specifically, the minimum number of test specimens for each sample, diameter of rods, thickness of rubber, overlap of tile beyond the edge supports, were determined according to ISO 10545 (Tab. 3 and 4).

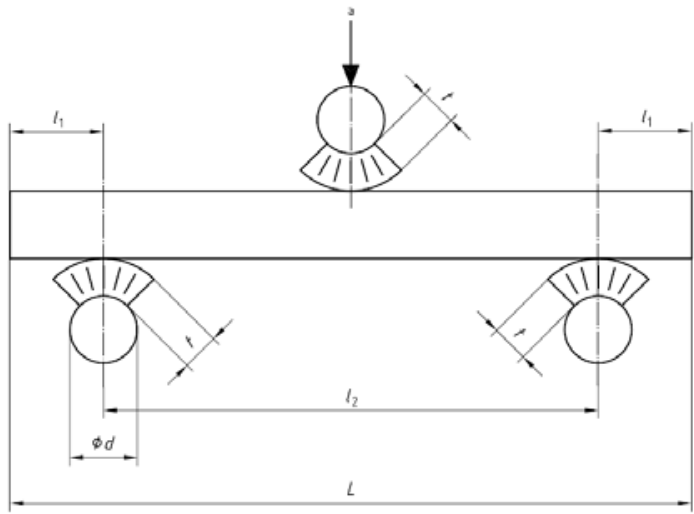

Figure 6: Application of loads to test specimen

Table 3, Technical specifications for application of loads

\begin{tabular}{|c|c|c|c|}
\hline $\begin{array}{c}\text { Diameter } \\
\text { of rods }\end{array}$ & $\begin{array}{c}\text { Distance } \\
\text { between } \\
\text { rods }\end{array}$ & $\begin{array}{c}\text { Overlap } \\
\text { of tile beyond } \\
\text { supports }\end{array}$ & $\begin{array}{c}\text { Rate of } \\
\text { application } \\
\text { of force }\end{array}$ \\
\hline $\mathrm{mm}$ & $\mathrm{mm}$ & $\mathrm{mm}$ & $\mathrm{mm} / \mathrm{s}$ \\
\hline $\mathrm{d}=14$ & 50 & $\mathrm{l}_{1}=25$ & 0.005 \\
\hline
\end{tabular}

Table 4, Technical specifications for specimens

\begin{tabular}{|c|c|c|c|c|}
\hline Length & Width & Thickness & Samples & Specimens \\
\hline \hline $\mathrm{mm}$ & $\mathrm{mm}$ & $\mathrm{mm}$ & $\mathrm{n}$. & $\mathrm{n}$. \\
\hline $\mathrm{L}=100$ & 20 & 9.5 & 2 & 7 \\
\hline
\end{tabular}

Specimens were installed on the testing machine with specific care to the correctness of positioning (Fig. 7).

All test on specimens were performed in a single experimental session with the same acquisition rate $(10 \mathrm{~Hz})$. Loads were applied in control of displacements. Rate of application of force was equal to $0.005 \mathrm{~mm} / \mathrm{s}$. According to the ISO 10545,

- breaking load $\left(F_{b l}\right)$ is the force necessary to cause the test specimen to break as read from the pressure gauge

- breaking strength $\left(\mathrm{F}_{\mathrm{bs}}\right)$ is the force obtained by multiplying the breaking load by the ratio (span between support rods)/(width of the test specimen)

- bending strength or modulus of rupture $\left(\mathrm{S}_{\mathrm{Fbs}}\right)$ is the quantity obtained by dividing the breaking strength by the square of the minimum thickness along the broken edge (on the base of a rectangular cross-section).
Experimental measures are reported in (Tab. 5, 6); stress-strain curves are reported in (Fig. 8, 9).
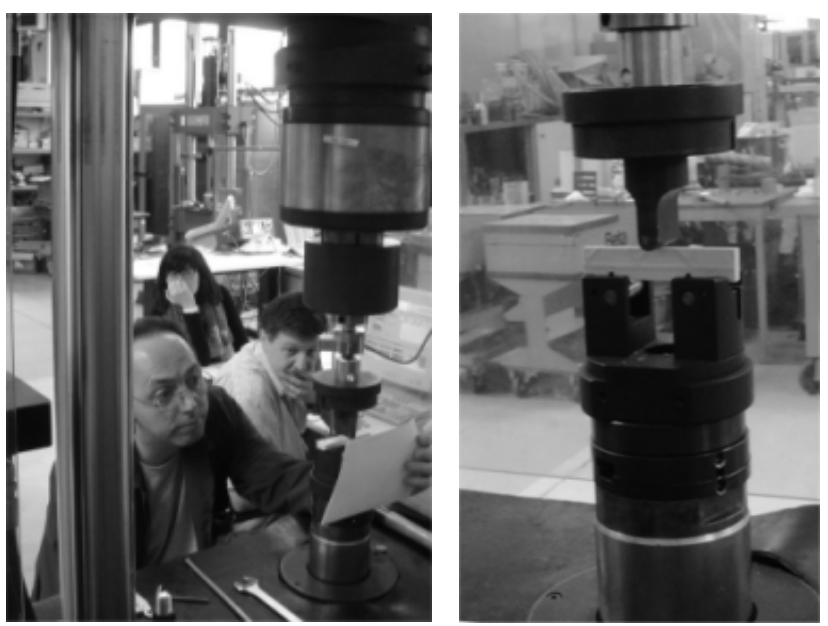

Figure 7: Installation of specimens

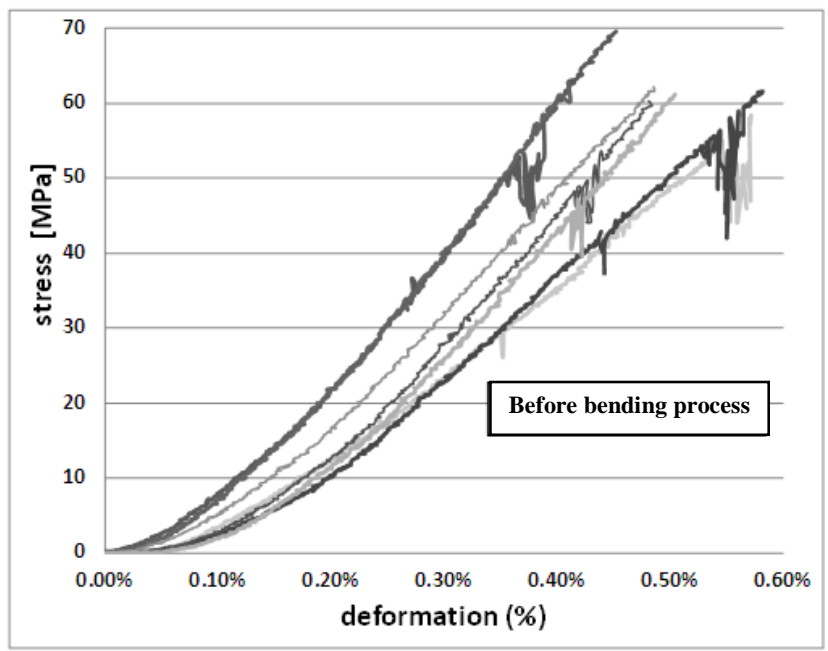

Figure 8: Stress - strain flexural diagrams for specimens extracted before the pyroclastic deformation

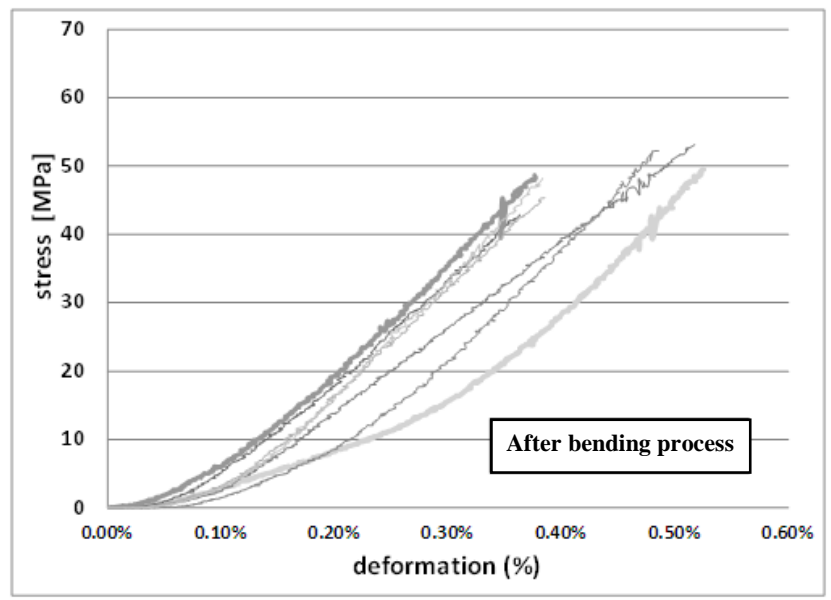

Figure 9: Stress - strain flexural diagrams for specimens extracted after the pyroclastic deformation 
Table 5, breaking loads, displacements, strengths and deformations observed from specimens extracted before the pyroclastic deformation of bending

\begin{tabular}{|c||c||c||c|c||c||}
\hline & Load & Strength & Stress & Strain & $\begin{array}{c}\text { Elastic } \\
\text { Modulus }\end{array}$ \\
\hline \hline Spec. & $\mathrm{kN}$ & $\mathrm{kN}$ & $\mathrm{MPa}$ & $\%$ & $\mathrm{MPa}$ \\
\hline \hline $\mathrm{I}$ & 1.452 & 3.630 & 61.186 & 0.509 & 12017 \\
\hline \hline $\mathrm{II}$ & 1.442 & 3.605 & 62.130 & 0.489 & 12704 \\
\hline \hline III & 1.481 & 3.703 & 62.831 & 0.417 & 15078 \\
\hline \hline $\mathrm{IV}$ & 1.668 & 4.169 & 69.572 & 0.454 & 15312 \\
\hline \hline $\mathrm{V}$ & 1.442 & 3.605 & 60.261 & 0.495 & 12174 \\
\hline \hline VI & 1.462 & 3.654 & 61.608 & 0.586 & 10510 \\
\hline \hline VII & 1.403 & 3.507 & 58.474 & 0.576 & 10154 \\
\hline mean & $\mathbf{1 . 4 7 9}$ & $\mathbf{3 . 6 9 6}$ & $\mathbf{6 2 . 2 9 4}$ & $\mathbf{0 . 5 0 4}$ & $\mathbf{1 2 5 6 4}$ \\
\hline \hline st. dev. & 0.087 & 0.217 & 3.505 & 0.061 & 2015 \\
\hline
\end{tabular}

Table 6, breaking loads, displacements, strengths and deformations observed from specimens extracted before the pyroclastic deformation of bending

\begin{tabular}{|c||c||c|c||c|c||}
\hline & Load & Strength & Stress & Strain & $\begin{array}{c}\text { Elastic } \\
\text { Modulus }\end{array}$ \\
\hline \hline Spec. & $\mathrm{kN}$ & $\mathrm{kN}$ & $\mathrm{MPa}$ & $\%$ & $\mathrm{MPa}$ \\
\hline $\mathrm{I}$ & 1.158 & 2.894 & 48.197 & 0.383 & 12572 \\
\hline \hline $\mathrm{II}$ & 1.010 & 2.526 & 45.373 & 0.416 & 10894 \\
\hline \hline $\mathrm{III}$ & 1.158 & 2.894 & 48.674 & 0.413 & 11779 \\
\hline \hline $\mathrm{IV}$ & 1.177 & 2.943 & 52.286 & 0.489 & 10687 \\
\hline \hline $\mathrm{V}$ & 1.177 & 2.943 & 53.082 & 0.529 & 10042 \\
\hline \hline $\mathrm{VI}$ & 1.010 & 2.526 & 42.863 & 0.365 & 11749 \\
\hline \hline VII & 1.167 & 2.918 & 49.492 & 0.529 & 9348 \\
\hline \hline mean & $\mathbf{1 . 1 2 3}$ & $\mathbf{2 . 8 0 6}$ & $\mathbf{4 8 . 5 6 7}$ & $\mathbf{0 . 4 4 6}$ & $\mathbf{1 1 0 1 0}$ \\
\hline \hline st. dev. & 0.077 & 0.193 & 3.605 & 0.068 & 1110 \\
\hline
\end{tabular}

\subsection{Comparing the flexural behaviour}

Experimental measures were used to compare mechanical flexural characteristic of grès porcelain before and after the pyroclastic deformation of bending process (Tab. 7). Compared graphs are also detailed (Fig. 10, 11).

Data and graphs shows that the bending process provokes:

- a significant reduction in mechanical resistance (22\%) showed by breaking loads and modulus of rupture

- a moderate diminution in ductility and elasticity emerging as reduction in breaking deformation ($11.4 \%)$ and elastic modulus (-12.4\%)

- a very limited increase in variability of characteristics

At the same time, even considering this alteration, it is evident that:

- breaking strength and bending strength (modulus of rupture) positively exceeds the limits reported in international standards (Tab. 8).
Table 7, deterioration of breaking loads, displacements, strengths and deformations provoked by the pyroclastic deformation of bending

\begin{tabular}{|c||c|c|c|c|c||}
\hline & Load & Strength & Stress & Strain & $\begin{array}{c}\text { Elastic } \\
\text { Modulus }\end{array}$ \\
\hline \hline & $\mathrm{kN}$ & $\mathrm{kN}$ & $\mathrm{MPa}$ & $\%$ & $\mathrm{MPa}$ \\
\hline$\Delta$ & -0.356 & -0.890 & $\mathbf{- 1 3 . 7 2 8}$ & -0.001 & -1554 \\
\hline $\mathbf{\%}$ & 24.1 & 24.1 & 22.0 & 11.4 & 12.4 \\
\hline
\end{tabular}

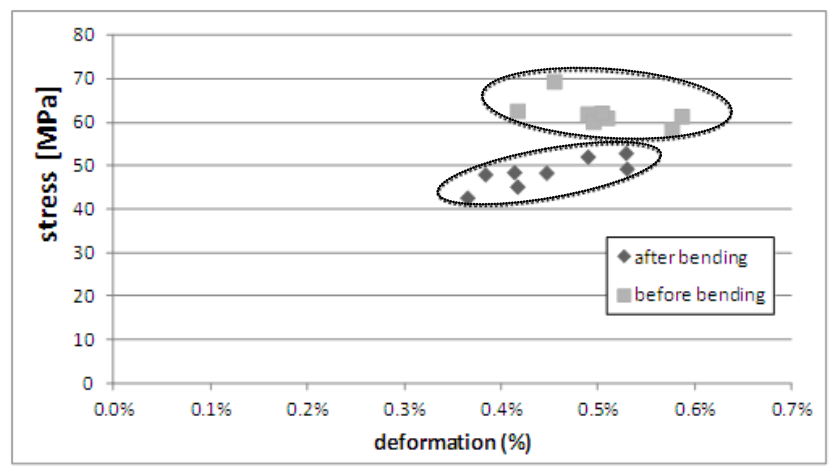

Figure 10: comparing the ultimate stress and strain for specimens extracted after and before the pyroclastic deformation of bending

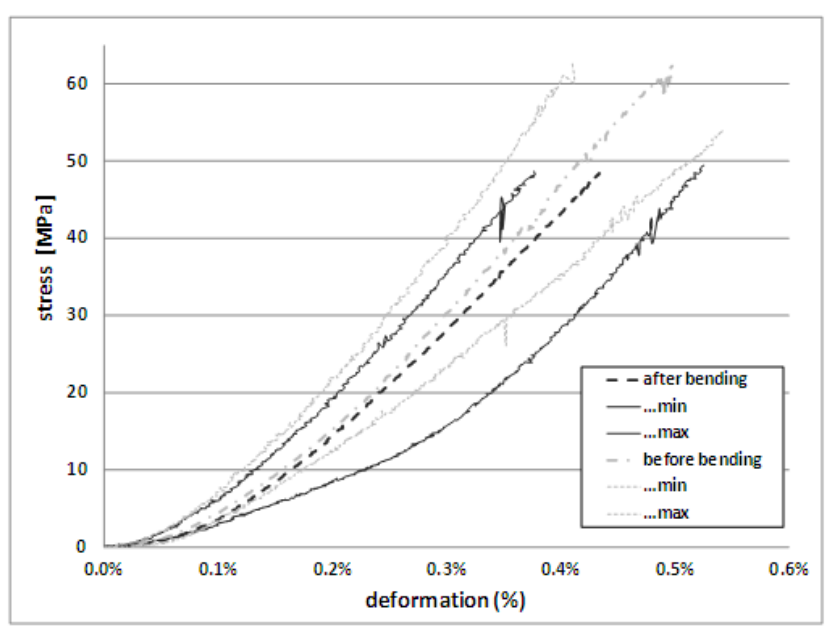

Figure 11: comparing stress - strain diagrams for (some) specimens extracted after and before the pyroclastic deformation of bending

Table 8, comparing breaking strength and bending strength with international standards

\begin{tabular}{||c|c|c|c||c||}
\hline $\begin{array}{c}\text { Specification } \\
\text { reference } \\
\text { ISO-10545-4 }\end{array}$ & $\begin{array}{c}\text { Before } \\
\text { bending }\end{array}$ & $\begin{array}{c}\text { After } \\
\text { bending }\end{array}$ & $\begin{array}{c}\text { Reference } \\
\text { value }\end{array}$ \\
\hline $\mathbf{7}$ & $\begin{array}{c}\text { Breaking } \\
\text { strength }\end{array}$ & 3696 & 2806 & $>1300 \mathrm{~N}$ \\
\cline { 1 - 4 } & $\begin{array}{c}\text { Bending } \\
\text { strength }\end{array}$ & 62 & 48 & $>35 \mathrm{MPa}$ \\
\hline
\end{tabular}




\section{IMPACT TESTS}

\subsection{Determination of impact resistance}

The UNI EN ISO 10545-5 [10] specifies a test method for determining the impact resistance of ceramic tiles by measuring the "coefficient of restitution between two impacting bodies". The determination is obtained by dropping a steel bail from a fixed height onto the test specimen and measuring the height of rebound. In particular, the coefficient of restitution is defined as the relative velocity of departure divided by the relative velocity of approach for the steel ball dropped.

This norm was created with the intent to compare ceramics by a standard procedure. This is the sole procedure referring to impacts on ceramics.

At the same time, it appears not appropriate for a larger utilisation. Specifically it intends to measure the capability of materials, laid on a rigid support, to react to a specific impact (fixed as energy). But it is hard to obtain by ISO 10545-5 in-depth information as, e.g., the minimal impact energy able to create a crack on specimen.

\subsection{Drop-weight impacts}

With the aim to obtain information on material behaviour respect to an increasing level of impact energy, impact tests were realized by a drop weight methodology.

The advantages of using an instrumented dropweight impact test are: (1) the initiation and development of damage during impact may be identified from a recorded impact force-time history curve; (2) several impact parameters can be examined; and (3) wide range of incident kinetic energies may be achieved by changing drop height and impactor mass.

\subsection{Drop-weight experiments}

The experiment consisted of series of drop-weight impact tests performed on ceramic specimens extracted before and after the pyroclastic deformation.

The impact tests were carried out using a dropweight machine equipped with an electro-optic device, for measurement of initial and final velocity of the impactor, and with a piezoelectric load cell attached to the impactor, for measurement of contact force history. The impactor head had the shape of hemisphere with $12.7 \mathrm{~mm}$ of diameter. Involuntary multiple collisions were avoided by means of an electromagnetic braking system. A detailed description of the machine can be found in [13]. The impactor mass was $1.22 \pm 0.01 \mathrm{~kg}$ and located to a specific height for its free-fall on specimen.

For each selected height, the free-fall impact speed was easily calculated as $V_{0}=\sqrt{2}$ gh. Considering that the initial impact speed can be only smaller than free-fall impacts peed, it is easy to conclude that the impacts in the experiment may be considered as low-velocity impacts, and treated as quasi-static mechanical processes.

Impacts were repeated with impactor released from the same height until penetration occurred in specimens. Not all specimens were penetrated by impactor.

N. 20 specimens were tested by drop-weight, half extracted before and half after the pyroclastic deformation.

\subsection{Comparing the impact behaviour}

By the analysis of experimental data from dropweight tests (Tab. 9), it was possible to estimate between 150 and 155 centimeters the height from which the impactor created a visible crack on ceramic specimens. This value is almost the same for the material before and after the pyroclastic deformation. At the same time, a difference in behavior could be observed. Specimens extracted before the additional thermal treatment on material better resisted to multiple impacts (up to 9 impacts without cracks), when impact energy was slightly lower than the limit of resistance. After treatment, the material was not able to resist to similar impacts and cracks arrived within the 2nd impact. It means that pyroclastic deformation also reduce the resistance to multiple impacts. These considerations remain almost the same if moving the attention from impact height to impact energy.

Table 9, impact tests with heights (in cm.) used for dropweight and number of repetitions for each specimen extracted before and after the pyroclastic deformation. Some specimens had no crack after multiple impacts (*)

\begin{tabular}{|c|c|c|c|c|c|}
\hline \multicolumn{3}{|c|}{$\begin{array}{c}\text { Before } \\
\text { bending }\end{array}$} & \multicolumn{3}{|c|}{$\begin{array}{c}\text { After } \\
\text { Bending }\end{array}$} \\
\hline Spec. & Height & Times & Spec. & Height & Times \\
\hline I & 500 & $\mathrm{x} 1$ & I & 145 & $\mathrm{x} 1$ \\
\hline II & 200 & $\mathrm{x} 1$ & II & 140 & $\mathrm{x} 2$ \\
\hline III & 150 & $\mathrm{x} 1$ & III & 140 & $\mathrm{x} 2$ \\
\hline IV & $130 *$ & $\mathrm{x} 5$ & IV & 130 & $\mathrm{x} 2$ \\
\hline V & 140 & $\mathrm{x} 2$ & V & 145 & $\mathrm{x} 2$ \\
\hline VI & $140^{*}$ & $\mathrm{x} 6$ & VI & 145 & $\mathrm{x} 2$ \\
\hline VII & 150 & $\mathrm{x} 2$ & VII & 150 & x3 \\
\hline IIX & 145 & $\mathrm{x} 2$ & IIX & 155 & $\mathrm{x} 1$ \\
\hline IX & 145 & $\mathrm{x} 4$ & IX & 155 & $\mathrm{x} 1$ \\
\hline$X$ & $145^{*}$ & x9 & $\mathrm{X}$ & 155 & $\mathrm{x} 1$ \\
\hline
\end{tabular}

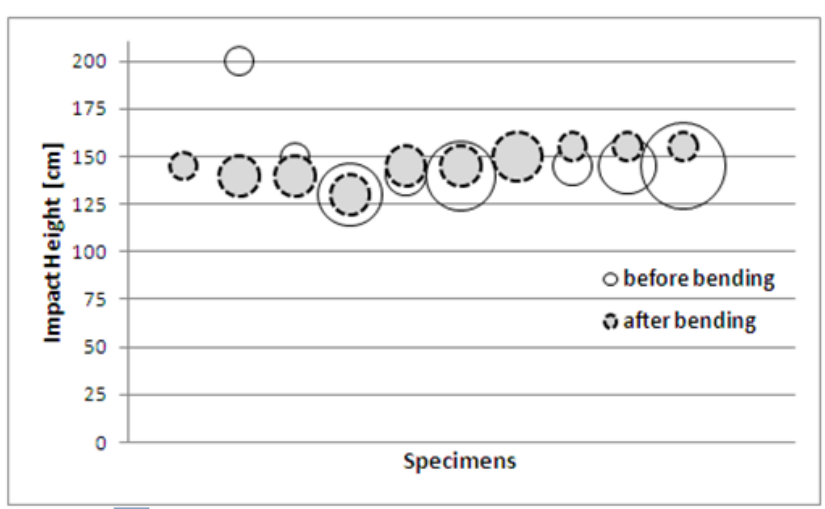

Figure 12: impact tests with heights used for drop-weight. The dimension of circles is proportional to number of ripetitions on specimens 


\section{COMPRESSIVE TESTS}

\subsection{The importance of compressive strength}

The compressive strength represents the resistance to crushing of a material subjected to load for crushing. Its assessment is of great interest to the materials that are used with structural functions and should therefore be able to withstand considerable loads (i.e. stone and ceramics as common bricks and refractory bricks). Bent tiles are always more frequently as functional components (e.g. steps in stairs). An estimation of compressive strength is mandatory.

\subsection{General aspects on tensile and compressive strengths} Ceramics are relatively fragile. The tensile strength of ceramic materials is very variable, ranging from very low values, of less than $0.7 \mathrm{MPa}$, up to about $7000 \mathrm{MPa}$ of some types prepared under carefully controlled conditions. In any case, a few ceramic materials have the tensile strength exceeding $170 \mathrm{MPa}$. Moreover, the ceramic materials show a great difference between their tensile and compression; typically the compressive strength is 5 to 10 times higher than the tensile strength, which shows the main differences in advanced ceramic materials [10]. Furthermore, many ceramic materials are hard and have a low toughness (low resistance to dynamic stress), due to the ion-covalent bonds.

\subsection{General aspects on hardness and compressive strength}

There is strict relation between elastic modulus and hardness of a material and its mechanical strength. The upper limit of the compressive strength of a material is defined as the stress to which it yields (i.e. deformation for sliding along the crystallographic planes). According to this definition of stress, a micro-plastic failure is in relation with the micro-hardness, measured by the Knoop or Vickers methods. In the case of various ceramic materials, the compressive strength corresponds to $1 / 2$ or $3 / 4$ of the stress of failure, calculated by dividing microhardness for 3. According to this formulation, a draft estimation for compressive strength can be obtained considering that hardness for Grès Porcelain stoneware, measured by Vickers method, is commonly between 750$830 \mathrm{HV}$. Consequently, the compressive strength is expected between 125-250 MPa.

\subsection{Compressive tests on ceramics}

There are not standards or common guidelines used to evaluate the tensile or compressive behavior of ceramics. UNI EN ISO 10545, detailed in 16 parts, specifies a test methods for determining several aspects of ceramics. Compression is not mentioned.

At the same time, the tensile strength of a simple compression in the stone coul be evaluated using the procedure described in the ISO 10545/3 [10], by a standardized vertical compression of specimens (the same as the procedure for the determination of the elastic tensile modulus for stones).

In this paper a complete experimental session for compressive test on ceramic specimens by ISO 10545/3 was also implemented (in completion for other tests). A preliminary evaluation of testing method is proposed.

\subsection{Limits respect to the application of standards}

N. 2 samples of 10 specimens were realized (from ceramic tiles before and after the bending process). Each sample included N. 10 cubic specimens with nominal dimension a $10 \times 10 \times 10 \mathrm{~mm}$. This dimension is lower than the minimal size declared in ISO 10545/3, but represents a possible upper limit in height according to the real dimensions of ceramic tiles

Before testing for compressive strength (Fig. 13), the dimensions of the specimen were measured in several positions and the mean values calculated. The crosssectional area of the loading faces were calculated. Three measurements of dimensions were made in each of the orthogonal directions ( $\mathrm{x}, \mathrm{y}, \mathrm{z})$. The accuracy of measure was around 5\% (higher than the $0.5 \%$ limit expressed in ISO 10545/3). Several specimens were ejected considering a relevant difference in dimensions respect to the designated size. The average area of each cube loading face was calculated.

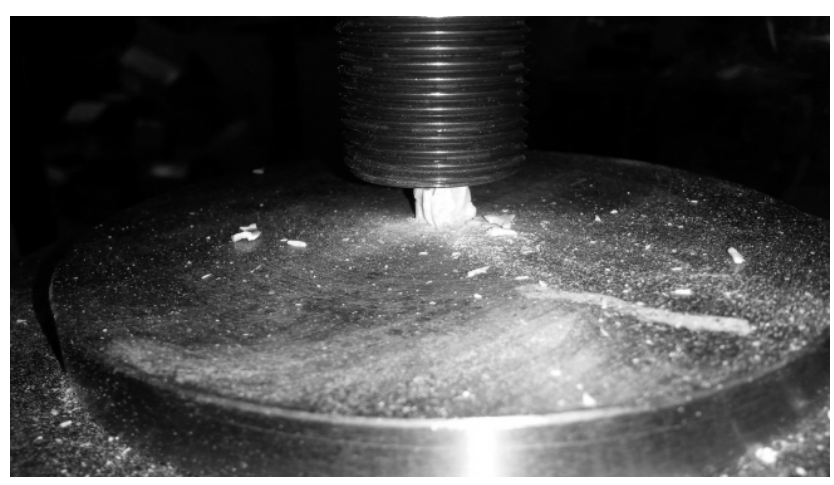

Figure 13: Compressive tests on ceramic specimens

\subsection{Stress-strain diagram for fragile materials}

The correct determination of the breaking strength by a compressive test in the case of fragile material is not a quite simple task. It has to take in count of additional aspects, as, e.g., the specific failure mechanism (if evident by observations).

In (Fig. 14) are reported stress-strain diagrams representing three different situations:

a. a negligible discontinuity in slope (at 138.5MPa) in a constantly ascending ramp. It represented marginal breaks inside the specimen (e.g. corners) with loss of fragments, evident by observations. Even if facing minor damages, since that moment, the specimen lost its integrity.

b. a discontinuity in slope (at 183.0MPa) with an evident downfall ( 20MPa) and a new ascending ramp with similar grade. It represented a significant break in microstructure continuity, also evident observing the specimen and its cracks during the application of load;

c. a complex diagram with a sequence of discontinuities in slope, after the first one (at 171.0MPa), up to the last downfall (to the zerostress). It represented the complete sequence of multiple fractures up to the definitive crumble. 


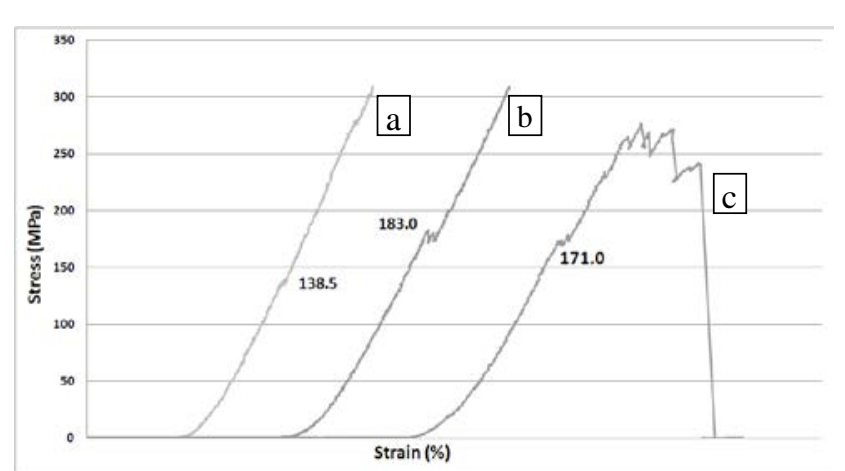

Figure 14: Example of different stress-strain diagrams for compressive tests.

\subsection{Determination of flexural breaking strength}

Compressive tests were performed on ceramic specimens extracted by tiles before and after the bending process. Measures were realized in a single experimental session. Testing machine was electronically limited with an upper of $25 \mathrm{kN}$ in loads (around 200Mpa on speciments). Not all measures releaved by experiments were appropriate for an univocal understanding. Some experimental measures had to be rejected since uncertainty on the failure mode.

A preliminary analysis of specimens is reported in (Fig. 15, 16) and (Tab. 9) where breaking strengths for are evident. In the case of specimens after bending, compressive strengths were in accordance with the expected values (as estimated in [6.3]).

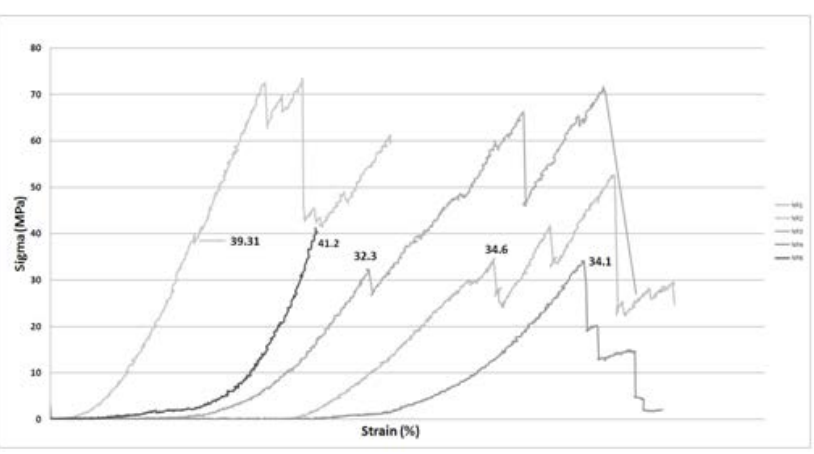

Figure 15: Compressive stress-strain diagrams for specimens extracted before the pyroclastic deformation of bending process

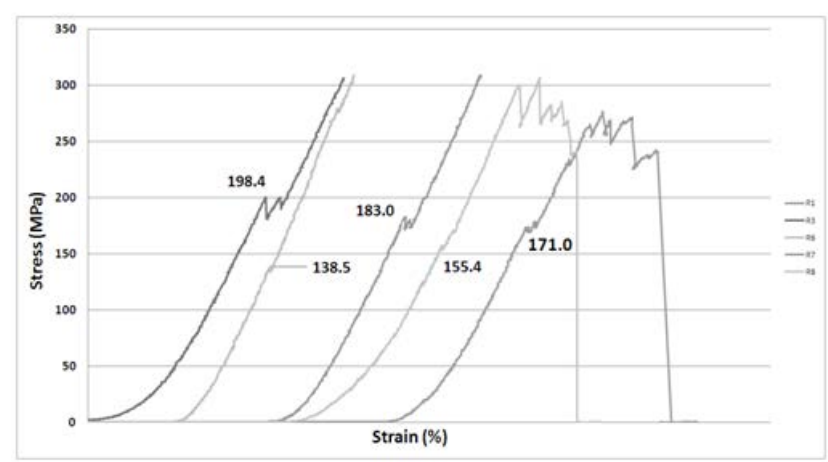

Figure 16: Compressive stress-strain diagrams for specimens extracted after the pyroclastic deformation of bending process

\begin{tabular}{|c|c|c|c|c|c|}
\hline \multicolumn{3}{|c|}{$\begin{array}{c}\text { Before } \\
\text { bending }\end{array}$} & \multicolumn{3}{|c|}{$\begin{array}{c}\text { After } \\
\text { bending }\end{array}$} \\
\hline Specimen & \begin{tabular}{|c|}
$\begin{array}{c}1 s t \\
\text { break }\end{array}$ \\
\end{tabular} & $\begin{array}{c}\text { last } \\
\text { break }\end{array}$ & Specimen & $\begin{array}{c}1 s t \\
\text { break }\end{array}$ & $\begin{array}{c}\text { Iast } \\
\text { break }\end{array}$ \\
\hline $\mathrm{I}$ & 39.3 & 73.2 & $\mathrm{I}$ & 198.4 & $>300$ \\
\hline II & 32.3 & 71.5 & II & 138.5 & $>300$ \\
\hline III & 34.6 & 52.9 & III & 183.0 & $>300$ \\
\hline IV & 34.1 & 34.7 & IV & 155.4 & 300 \\
\hline $\mathrm{V}$ & - & 41.2 & $\mathrm{~V}$ & 171.0 & 275 \\
\hline \multirow[t]{2}{*}{ mean } & 35.01 & 54.7 & mean & 169.3 & $>300$ \\
\hline & $M P a$ & $M P a$ & & $M P a$ & $M P a$ \\
\hline
\end{tabular}

Table 9, compressive breaking strengths from specimens extracted before and after the pyroclastic deformation

\subsection{Comparing the compressive behaviour}

Experimental measures were used for a preliminary comparative analysis of compressive behaviour of grès porcelain before and after the bending process. Data suggested that the additional heating treatment, related to the bending process, provokes a net change in the material behaviour. Specifically, referring, for instance, to the stress/strain diagrams:

- lower values for peaks

- smoother curves

- steeper slopes

- less variability in shape

are graphical effects of ceramic pyroclastic deformation.

These evidences could be explained with a general reduction in the grade of brittleness of material. The additional heating treatment, even if realized at lower temperature respect to the sintering, could be relevant in a better compacting of fundamental the elements.

The first breaks, usually evident at very low stress, around 32-45 MPa for untreated materials, and referred to marginal fractures, disappear by this secondary treatment. The zigzag in stress-strain curve, representing the sequence of partial breaks in a nevertheless improving level of stress, also disappear in treated materials. These "new" ceramics appear able to provide a more constant resistance to compressive forces. In other terms, instead to react by means of partial cracks to an increase of loads, after the pyroclastic deformation, the material responds in a more homogeneous way. As a consequence, compressive strengths increase and different trends appear in diagrams.

\subsection{Limits of the analysis}

For all the experimental evidences listed in the previous paragraph, it could be possible to find theoretical explanations. Some of these justifications could be also related to results from the state of arts. At the same time, there is no any logical reason able to explain the enormous difference between the values of compressive resistance for materials before and after the thermal treatment. The previous characterisations limited this difference to $25 \%$.

Without further evidences, it is obligatory to accept that ISO $10545 / 3$ is not even appropriate for a very draft estimation of compressive behavior of ceramic tiles 


\section{CONCLUSIONS}

Grès Porcelain stoneware is a largely used ceramic material. A very interesting technology permits to obtained innovative solutions by bended porcelain tiles. This technology is able to add new functions to tiles. But a better knowledge on material proprieties is required.

This paper investigated the alteration behaviour of porcelain passing by the bending process comparing mechanical proprieties by bending, compression and impact tests. Specifically, it is possible to affirm that the bending process reduces the mechanical resistance, in the meaning of flexural breaking loads and flexural modulus of rupture, for about $22 \%$. A moderate diminution in elasticity also emerges, together with a change in the behaviour of material, as an increase in fragility during the flexural tests (static response), This information is also confirmed by the impact tests (dynamic response). At the same time, no significant reduction in the resistance to impact is evident.

Adding, this paper highlighted the current limit of international standards if applied to the new class of ceramics that are emerging. At the moment standards consider tiles in their simple role of "covering elements for pavement”. While Grès Porcelain tiles, with benefit and advantages, are going to assume a more complex profile of potential applications. Far away from advanced ceramics, bent tiles start to feel its family of ceramics to little. Compressive tests are not ruled by standards, but would be useful for a correct design, use and installation of bent tiles. Even the impact tests, largely used to compare ceramics in a standard way, are not appropriate for indepth comprehension of mechanical proprieties. The paper started an investigation on the possibility (or the limits) to applied standards coming from other fields of applications. As preliminary results, drop-weight standard methodology appears already appropriate to provide interesting results on impact behaviour of materials or components. On the contrary, compressive test methodologies, largely applied with success in other situations (e.g. on concrete), cannot be used since insuperable limitations.

\section{ACKNOWLEDGEMENTS}

Research presented in this paper was supported by the Emilia Romagna Italian Region inside the programme "From Productive Districts to Technologic Districts Actions for straightening and orienting the technological productive districts in Emilia Romagna" and, specifically, for the Materials and of Technologies for Ceramics. The related R\&D project, named as "Setup of products in ceramics with additional functionalities", is realized by a network of small medium enterprises (Levikurve, R.T.C. Ricerca Tecnico Ceramica, Keser Italia), in collaboration with the University of Bologna and under the supervision on Confindustria, the main organisation representing Italian manufacturing and services companies.

\section{REFERENCES}

[1] "Ceramic tiles. Definitions, classification, characteristics, evaluation of conformity and marking” UNI EN ISO 14411:2012 (including UNI EN ISO 13006)

[2] M. Dondi, G. Ercolani, M. Marsigli, C. Melandri, C. Mingazzini, "The Chemical Composition of Porcelain Stoneware Tiles and its Influences on Microstructure and Mechanical Proprieties”. Interceram 48 [2], pp. 75-83, (1999)

[3] A. F. Gualtieri, "Thermal Behavior of the Raw Materials Forming Porcelain Stoneware Mixture by Combined Optical and In Situ X-Ray Dilatometry”, J. Am. Ceram. Soc. 90, pp 1222-1231, (2007)

[4] A. Salem, S. H. Jazayeri, A. Tucci, G. Timellini, "Influence of Firing Temperature and Soaking Time on Sintering of Porcelain Stoneware Tiles”. CFI-Ceram. Forum Int. 80 [9], E66, (2003)

[5] Yu. G. Tkachenko, D. Z. Yurchenko, V. K. Sul'zhenko, G. S. Oleinik, and V. M. Vereshchaka, "Temperature Effect on Bending Strength of Hot-Pressed Boron Carbide Materials”, Powder Metallurgy and Metal Ceramics, Vol. 46, Nos. 5-6, 2007

[6] A, Serri, L. Luberto, "23th Statistical Survey on Grès Porcelain”, Confindustria Ceramica, Sassuolo (Italy), (2011)

[7] R. Fabbroni, “A Process for Modeling Ceramic Tiles”, Patent N. WO/2003/800302, Applicant: Keser Diva Design S.p.A. Faenza (Italy), (2003)

[8] A. M. Bernardi, D. S. Demedeiros, H. G. Riella, "Pyroplasticity in Porcelain Tiles". Mater. Sci. Eng. A427, pp. 316-318, (2006)

[9] "Regulation (EC) 852/2004 on the hygiene of foodstuffs"; Official Journal of the European Union, L 226, 25 June 2004; Volume 47; ISSN 1725-2555

[10] P.P. Conti, “An Improved Method for Bending Ceramic Tiles”, Patent N. WO/2014/064720; 01/05/2014; Applicant: Brevetti 2000 Srl, Italy (Italy), (2014)

[11] "Ceramic tiles — Part 4: Determination of modulus of rupture and breaking strength”, UNI EN ISO 105454:2004

[12] "Ceramic tiles — Part 5: Determination of impact resistance by measurement of coefficient of restitution”, UNI EN ISO 10545-5:1996

[13] Zucchelli, A., Minak, G., Ghelli, D. Low-velocity impact behavior of vitreous-enameled steel plates (2010) International Journal of Impact Engineering, 37 (6), pp. 673-684.

[14] W. A..Dunlay, C. A. Tracy, P. J. Perrone “A Proposed Uniaxial Compression Test for High Strength Ceramics”, U.S. Army Materials Technology Laboratory, MTL TR 89-89 (1989)

[15] "Testing hardened concrete — Part 3: Compressive strength of test specimens”, UNI EN ISO 12390-1 2002 